\title{
Transgenic Tobacco Lines Expressing Yam Mosaic Virus Coat Protein-Derived dsRNA Are Resistant to Yam Mosaic Virus
}

\author{
Effiom Eyo Ita1,2, Edak Aniedi Uyoh'1, Ikuo Nakamura², Valentine Otang Ntui1,3* \\ ${ }^{1}$ Department of Genetics \& Biotechnology, University of Calabar, Calabar, Nigeria \\ ${ }^{2}$ Laboratory of Plant Cell Technology, Graduate School of Horticulture, Chiba University, Chiba, Japan \\ ${ }^{3}$ International Institute of Tropical Agriculture, Nairobi, Kenya \\ Email: *ntuival@yahoo.com, *v.ntui@cgiar.org
}

How to cite this paper: Ita, E.E., Uyoh, E.A., Nakamura, I. and Ntui, V.O. (2020) Transgenic Tobacco Lines Expressing Yam Mosaic Virus Coat Protein-Derived dsRNA Are Resistant to Yam Mosaic Virus. American Journal of Plant Sciences, 11, 1487-1504. https://doi.org/10.4236/ajps.2020.119108

Received: July 19, 2020

Accepted: September 25, 2020

Published: September 28, 2020

Copyright $\odot 2020$ by author(s) and Scientific Research Publishing Inc. This work is licensed under the Creative Commons Attribution International License (CC BY 4.0).

http://creativecommons.org/licenses/by/4.0/

\begin{abstract}
Yam mosaic virus (YMV), a Potyvirus, is a highly destructive pathogen of yam accounting for yield losses up to $40 \%$. Apart from causing significant reduction in tuber size and quality, it restricts international exchange of germplasms. It thus becomes crucial to get resistant or at least virus-free planting materials for farmers. This study was aimed at inducing resistance to YMV in tobacco by RNA silencing. An RNAi construct containing $161 \mathrm{bp}$ fragment of YMV-coat protein $(\mathrm{CP})$ gene was developed and used to produce transgenic tobacco lines expressing YMV-coat protein (CP) derived double stranded RNA (dsRNA) via Agrobacterium-mediated transformation. Of the eight $\mathrm{T}_{1}$ transgenic lines inoculated with YMV, six (L1, L2, L3, L5, L7 and L8) showed immunity to YMV as no symptoms were detected, whereas two (L4 and L10) exhibited high resistance with mild symptoms limited to inoculation portions. No virus could be detected in uninoculated new leaves of the transgenic lines after RT-PCR and qPCR analyses of YMV-coat protein (CP). The presence of small interfering RNAs in transgenic lines after virus challenge indicates that the resistance was acquired through RNA silencing.
\end{abstract}

\section{Keywords}

Yam Mosaic Virus, dsRNA, PTGS, Coat Protein Gene, RNAi

\section{Introduction}

Yam mosaic virus (YMV), a member of Potyvirus, is a single stranded positive-sense RNA virus [1] [2]. It is a highly destructive pathogen of yam (Dioscorea spp.). Infected plants usually show leaf green vein-banding, inter-veinal 
mosaic, curling, molting and stunted growth, and the disease can result in significant yield losses in yam [3] [4]. The virus is transmitted by aphids in a non-persistent manner, as well as through vegetative propagation. In nature, YMV has been found in several species of Dioscoreaceae [1] [4] [5] [6] and can be mechanically transmitted to Nicotiana benthamiana, N. megalosiphon and Chenopodium amanticolor [5]. Due to the wide host range and devastating effects of the virus, farmers and researchers have tried several strategies to introduce resistance to YMV by conventional breeding method and by genetic engineering.

Post-transcriptional gene silencing (PTGS) is an RNA silencing-based mechanism used to reduce the level of expression of a gene of interest. It has been described in many eukaryotic organisms including fungi, invertebrates, vertebrates and plants. It is termed quelling in fungi [7] and RNA interference in animals [8]. The mechanism of PTGS involves the sequence-specific degradation of RNA and several different techniques have been developed to achieve this in plants. In RNAi-mediated silencing, the constructs are usually designed such that when the transgene is expressed in plants, it produces double stranded RNAs (dsRNAs,) which are cleaved into short dsRNA fragments known as "Short interfering RNAs (siRNAs)" of $21-25$ bp in length [9] [10], by a ds-specific ribonuclease termed "Dicer" [11]. The strand of siRNA complementary to target RNA becomes incorporated into the RNA-induced silencing complex (RISC) leading to mRNA degradation and gene silencing [9].

Many documented evidences have shown that RNAi can be engineered to target viral RNA [12] as well as DNA viruses [13] in plants. There are several reports on the application of RNAi in plants to induce resistance to several viruses including African cassava mosaic virus [14], Sri Lanka cassava mosaic virus (SLCMV) [15], Cucumber mosaic virus, Zucchini yellow mosaic virus and Watermelon mosaic virus [16]-[21], Bean golden mosaic virus [9], Potato leaf roll virus, Potato virus $Y$ and Potato virus $X$ [22] [23], Papaya ring spot virus [24] and Plum pov virus [25] [26]. Up to date, no report has documented the use of YMV Coat Protein (YMV-CP) gene to express dsRNA in transgenic plants. Therefore, the aim of this study was to induce resistance to YMV in tobacco by RNA silencing of YMV-CP as a proof of concept.

\section{Materials and Methods}

\subsection{RNAi Vector Construction}

Yam mosaic virus coat protein (YMV-CP) gene sequences of different isolates of yam mosaic virus (gi|7414928|emb|AJ244066.1, gi|14589250|emb|AJ305443.1, gi|14589246|emb|AJ305441.1, gi|14589244|emb|AJ305440.1, gi|14589242|emb|AJ305439.1, gi|14589238|emb|AJ305437.1, gi|14589234|emb|AJ305435.1, gi|7414926|emb|AJ244065.1, gi|7414924|emb|AJ244064.1, gi|7414922|emb|AJ244063.1, gi|7414920|emb|AJ244062.1, gi|7414918|emb|AJ244061.1, 
gi|7414916|emb|AJ244060.1 and gi|7414914|emb|AJ244059.1) were downloaded from NCBI. The sequences were aligned using Multalin (http://multalin.toulouse.inra.fr/multalin/) to identify conserved region. Primers were designed to amplify $161 \mathrm{bp}$ fragment in the conserved region. Total RNA was extracted from YMV infected leaves using RNeasy ${ }^{\oplus}$ Plant Mini Kit (QIAGEN GmbH, Germany) and cDNA was synthesized from $1 \mu \mathrm{g}$ of total RNA using iScript cDNA Synthesis Kit (BIO-RAD Laboratories, Inc.) according to the manufacturer's instructions. One $\mu$ of the cDNA was then used for PCR analysis to amplify YMV-CP gene using the primers YMV-CP5P and YMV-CP3P (Table 1). After amplification, $5 \mu \mathrm{L}$ of PCR product was resolved on $1 \%$ agarose gel stained with gel red.

The PCR product was purified using QIAquick PCR purification Kit (QIAGEN) and subsequently cloned into Gateway entry vector $p C R^{n} 8 / G W / T O P O^{\circledast}$ (Invitrogen, New Zealand), which contains attL1 and attL2 recombination sites. The ligated product was transformed to TOP10 E. coli competent cells and selected on LB medium containing spectinomycin $(100 \mathrm{mg} / \mathrm{L})$. Ten colonies were selected, plasmid DNA extracted and verified by Sanger sequencing using M13primers. The correct transformant containing the $161 \mathrm{bp}$ YMV-CP was subcloned in the sense and antisense orientation to the pANDA35HK RNAi destination vector by LR clonase reaction using Gateway LR Clonase II enzyme mix (Thermo Fisher Scientific). The product was transformed to DH5a E. coli chemical competent cells and selected on LB plates containing $50 \mathrm{mg} / \mathrm{L}$ kanamycin. Plasmid was extracted from transformants using FastGene plasmid Mini Kit (NIPPON GENETICS Co., Ltd. Japan) and confirmed by digestion with Sac1 and Kpn1. One positive clone was selected and mobilized to Agrobacterium tumefaciens strain EHA105 by the Freeze-Thaw method and selected on LB plate containing $50 \mathrm{mg} / \mathrm{L}$ kanamycin and $25 \mathrm{mg} / \mathrm{L}$ Rifampicin. Plasmids were extracted from positive colonies using FastGene plasmid Mini Kit (NIPPON GENETICS Co., Ltd. Japan) and checked by PCR and by digestion with SacI and KpnI.

\subsection{Transformation of Nicotianatabacum with the RNAi Construct}

Leaves of Nicotiana tabacum (cv. Havana) were used for transformation using the Agrobacterium-mediated leaf disc method [27]. Agrobacterium tumefaciens strain EHA105 containing pANDA35HK-YMV-CP was grown overnight on a reciprocal shaker $(120 \mathrm{cycles} / \mathrm{min})$ at $28^{\circ} \mathrm{C}$ in $20 \mathrm{ml} \mathrm{LB}$ medium containing 50 $\mathrm{mg} / \mathrm{L}$ kanamycin and $25 \mathrm{mg} / \mathrm{L}$ Rifampicin. The overnight culture was centrifuged for $10 \mathrm{~min}$ at 10,000 rpm and re-suspended in $30 \mathrm{ml} \mathrm{MS}$ medium (inoculation medium) and left at room temperature for $30 \mathrm{~min}$ before inoculation. Leaves from in vitro plants were excised, cut into portions of $5-8 \mathrm{~mm}$ square and dipped in the bacterial suspension for $10 \mathrm{~min}$ with gentle shaking at room temperature. After inoculation, the explants were blotted dry and co-cultivated for 3 days in the dark on hormone free MS medium containing $100 \mu \mathrm{M}$ acetosyringone and solidified with $8 \mathrm{~g} / \mathrm{L}$ Agar, $\mathrm{pH}$ 5.8. At the end of the co-cultivation 
period, the explants were washed three times with sterilized distilled water and cultured on MS medium supplemented with $30 \mathrm{~g} / \mathrm{L}$ sucrose, $8 \mathrm{~g} / \mathrm{L}$ agar, $20 \mathrm{mg} / \mathrm{L}$ meropenem trihydrate (Meropenem; Dainippon Sumitomo Pharma, Osaka, Japan) [28] to eliminate bacterial carry over, and with hygromycin $(40 \mathrm{mg} / \mathrm{L})$ to select for transformants. The explants were sub-cultured at 2-week intervals to fresh medium of same composition. After 4 weeks of culture, adventitious shoots were excised and transferred to hormone-free MS medium containing $20 \mathrm{mg} / \mathrm{L}$ meropenem trihydrate and $40 \mathrm{mg} / \mathrm{L}$ hygromycin for development and rooting. Rooted plantlets were maintained in vitro in the growth room with subculture every 8 weeks.

\subsection{Molecular Characterization of $T_{0}$ Transgenic Plants}

\subsubsection{PCR for Detection of YMV-CP Transgene}

DNA was extracted from leaves of putative $\mathrm{T}_{0}$ transgenic plants using Cetyltrimethylammonium bromide (CTAB) method and used for PCR to detect the presence of the YMV-CP transgene using the primers YMV-CP5P and YMV-CP3P (Table 1). The selectable marker gene hpt and guslinker were also detected using the primers Hyg5Pin and Hyg3Pin as well as GUSLK-F GUSLK-R (Table 1). The PCR reaction was constituted in a $50 \mu \mathrm{L}$ reaction volume containing distilled water $36.6 \mu \mathrm{L}, 5 \mu \mathrm{L}$ 10X Ex Taq buffer (1X), $5 \mu \mathrm{L}$ dNTPs (200 $\mu \mathrm{M}), 1 \mu \mathrm{L}$ YMV-CP-5P $(0.2 \mu \mathrm{M}), 1 \mu \mathrm{L}$ YMV-CP-3P $(0.2 \mu \mathrm{M}), 0.40 \mu \mathrm{L}$ Ex Taq (1.25 units), and $1 \mu \mathrm{L}$ DNA. The PCR conditions were: initial denaturation at $94^{\circ} \mathrm{C}$ for $5 \mathrm{~min}, 35 \mathrm{cycles}$ of denaturation at $94^{\circ} \mathrm{C}$ for $30 \mathrm{sec}$, annealing at $58^{\circ} \mathrm{C}$ $\left(60^{\circ} \mathrm{C}\right.$ for $\left.h p t\right)$ for $40 \mathrm{sec}$, extension at $72^{\circ} \mathrm{C}$ for $50 \mathrm{sec}$, followed by final extension at $72^{\circ} \mathrm{C}$ for $7 \mathrm{~min}$ and holding at $4^{\circ} \mathrm{C}$ forever. The amplified products were separated in $1 \%$ agarose gel subjected to electrophoresis at $100 \mathrm{~V}$ for $30 \mathrm{~min}$ and stained with ethidium bromide.

Table 1. Primers used for amplification.

\begin{tabular}{cc}
\hline Primer & Primer Sequence \\
YMV-CP5P & 5'-GTGGACAATGATGGACGGTG-3' \\
YMV-CP3P & 5'-CGTATCGGGGCATATACGGT-3' \\
Hyg5Pin & 5'CAGCTTCGATGTAGGAGGGCGTGG-3' \\
Hyg3Pin & 5'-AATCCCCGAACATCGCCTCGCTCC-3' \\
GUSLK-F & 5'-CATGAAGATGCGGACTTACG-3' \\
GUSLK-R & 5'-ATCCACGCCGTATTCGG-3' \\
YMV-CP_qPCR-F & 5'-CAGATATGCGTTCGACTTCTTA-3' \\
YMV-CP_qPCR-R & 5'-AGGCTGTGCATGTCTTTC -3' \\
Yam_Ubq-F & 5'-CAGTCATGGTGCGATGTT-3' \\
Yam_Ubq-R & 5'-CCTCACAACTTCCAAGAGTTC-3' \\
\hline
\end{tabular}




\subsubsection{Southern Blot Analysis of Genomic DNA from Transgenic and Wild Type Plants}

For Southern blot, $15 \mu \mathrm{g}$ of the DNA of wild-type and transgenic tobacco lines were digested with $\mathrm{XhoI}$ at $37^{\circ} \mathrm{C}$ overnight. The products of the enzyme digestion were separated on $0.8 \%$ agarose gel and transferred to a positively charged nylon membrane (Immobilion ${ }^{\oplus} \mathrm{Ny}+$ Transfer Membrane; Millipore Co., Billerica, MA, USA). After transfer, the DNA was fixed to the blot and hybridized. Prehybridization $(3 \mathrm{~h})$ and hybridization (overnight) were carried out at $42^{\circ} \mathrm{C}$, using DIG Easy Hyb buffer and HPT probe. The probe was generated from pANDA35HK-YMV-CP and labeled using PCR DIG probe synthesis Kit (Roche Diagnostic GmbH, Boehringer Mannheim, Germany) with the primers Hyg5Pin and Hyg3Pin. Post-hybridization washes and chemiluminescence detection using CDP star were performed according to the instruction in DIG Application Manual for Filter Hybridization (Roche Diagnostics, Mannaheim, Germany).

\subsection{Bioassay of $\mathrm{T}_{0}$ Transgenic Plants}

\subsubsection{Evaluation of $T_{0}$ Transgenic Tobacco Lines for Resistance to YMV}

Rooted wild-type and transgenic plants confirmed by PCR were hardened, grown in the greenhouse and sap inoculated with YMV. Sap extract was prepared by crushing yam mosaic virus infected yam leaves in inoculation buffer (0.1 M sodium phosphate buffer, $\mathrm{pH}$ 7.5). After 4 weeks, following establishment of the plants in the greenhouse, the plants were sap inoculated with the YMV sap extract by gently robbing onto two completely opened young leaves with the help of carborundum as an abrasive agent [19]. Three days after the first inoculation, another young leaf was cut off at the node. The cut surface on the stem was inoculated with the YMV sap extract by gently robbing the cut surface with the extract using cotton bud. In parallel, mock control plants were inoculated with $0.1 \mathrm{M}$ sodium phosphate buffer only. Inoculated plants were maintained in a walk-in growth chamber at $24^{\circ} \mathrm{C}$. Symptom development was assessed every alternate day but the final classification was recorded 45 days post inoculation (dpi) and photographs of the plants taken. The number of plants showing mosaic symptoms, plant height and number of leaves per plant showing mosaic symptoms were also recorded at $45 \mathrm{dpi}$. Disease symptom severity on fully expanded leaves was recorded on a scale of 0-3 (0, no symptom; 1-mild chlorotic pattern over entire leaflet; 2-moderate mosaic pattern throughout the leaf, narrowing and distortion of the lower one-third of leaflets; 3 -severe mosaic, distortion of two-thirds of the leaflets). Disease index was calculated using the method described by [15] as follows:

$$
\text { D.I }=\frac{\left(n_{1}+2 n_{2}+3 n_{3}\right) 100}{3\left(n_{0}+n_{1}+2 n_{2}+3 n_{3}\right)}
$$

where D.I is Disease Index, $\mathrm{n}$ is the number of leaves in each grade (0-3) with respect to the symptom severity score. Plants with a disease index of $0 \%$ were considered as immune, those with a disease index $<25 \%$ as having high levels of resistance (HR), those with a disease index of $25.1 \%-50.0 \%$ as being moderately 
resistant (MR), those with D.I of 50.1 - 75.1 susceptible (S), and those with D.I of $75.1 \%-100 \%$ as highly susceptible (HS).

\subsubsection{Determination of Viral Load by RT-PCR}

Total RNA was extracted from uninoculated new leaves that emerged from plants challenged with YMV using RNAiso Plus kit, TaKaRa (TAKARA BIO INC. Japan). cDNA was synthesized using PrimScript ${ }^{\mathrm{Tm}}$ RT reagent Kit containing gDNA Eraser (Perfect Real Time) by TaKaRa (TAKARA BIO INC. Japan). The cDNA synthesized was used for RT-PCR to detect the presence of yam mosaic virus using the primers YMV-CP_qPCR-F and YMV-CP_qPCR-R (Table 1). Yam ubiquitin gene was used as internal control to check the quality of the cDNA using the primers Yam_Ubq-F and Yam_Ubq-R (Table 1). The amplified products were resolved on $1 \%$ agarose gel stained with ethidium bromide.

\subsection{Northern Blot Analysis of $\mathrm{T}_{0}$ Plants for Detection of siRNA after Virus Challenge}

Transgenic $\mathrm{T}_{0}$ tobacco lines together with the control plants were analyzed for siRNA accumulation after challenge with YMV. Small RNAs ( $<200$ bp) were extracted using ISOGEN II reagent (Nippon Gene). Thirty micrograms of small RNAs were electrophoresed on a $17 \%$ polyacrylamide gel containing $7 \mathrm{M}$ urea and 10X Tris Borate EDTA (TBE). siRNAs were transferred to Immobilon-NY+ membrane (Millipore Corporation, Billerica, MA, USA) in a semi-dry cell (Semi-dry blotting apparatus NA-1512, Nippon Eido, Tokyo, Japan) for $1 \mathrm{~h}$ at10 $\mathrm{V} / 400 \mathrm{~mA}$ and subjected to northern hybridization with a probe obtained by the in vitro transcription of the YMV-CP gene in the antisense and sense orientation using T7 RNA polymerase according to DIG Northern Starter Kit Version 10 (Roche) protocol. Prehybridization (30 $\mathrm{min}$ ) and hybridization (overnight) were performed at $50^{\circ} \mathrm{C}$. Post-hybridization stringency washes and chemiluminescent detection of siRNA signals using CDP-star were performed following protocols outlined in the DIG Northern Starter Kit manual (Roche Diagnostic GmbH, Boehringer Mannheim, Germany).

\subsection{Bioassay of $T_{1}$ Transgenic Plants}

\subsubsection{Evaluation of $\mathrm{T}_{1}$ Transgenic Tobacco Lines}

$\mathrm{T}_{1}$ candidate seeds were collected from $\mathrm{T}_{0}$ plants and germinated in Petri dishes containing half strength of MS basal salts and vitamins supplemented with 40 $\mathrm{mg} / \mathrm{L}$ hygromycin for selection, and solidified with $3 \mathrm{~g} / \mathrm{L}$ gelrite. One week after germination, the seedlings were transferred to the soil. The seedlings were screened for the presence of the target transgene and the selectable marker gene by PCR with the primers YMV-CP5P and YMV-CP3P as well asHyg5Pin and Hyg3Pin, before being transferred to the greenhouse in bigger pots containing garden soil. After 4 weeks, following establishment of the plants in the greenhouse, they were inoculated with YMV sap extract by gently robbing onto two completely opened young leaves as earlier described. Symptom development was assessed every alternate day but the final classification was recorded 45 days post 
inoculation (dpi). Disease symptom severity on fully expanded leaves was recorded and disease indices computed as earlier described.

\subsubsection{Determination of Virus Accumulation by qPCR}

Total RNA was extracted from un-inoculated new leaves that emerged from plants challenged with YMV using RNAiso Plus by TaKaRa (TAKARA BIO INC. Japan). gDNA was eliminated from the total RNA and cDNA was synthesized using PrimScript ${ }^{\text {tw }}$ RT reagent Kit with gDNA Eraser (Perfect Real Time). The cDNA synthesized was used for Real Time RT-PCR to quantify YMV viral load in both wild-type and $T_{1}$ transgenic yam plants challenged with YMV. Primers used were: YMV-CP_qPCR-F and YMV-CP_qPCR-R; Ubq-qPCR-F and Ubq-qPCR-R (Table 1). Real Time PCR was performed on Applied BiosystemsStepOne $^{\mathrm{T} x}$ and StepOnePlus ${ }^{\mathrm{Tx}}$ Real Time PCR system (Applied Biosystems Japan Ltd.) using KOD SYBR ${ }^{\circledR}$ qPCR Mix (TOYOBO Company Limited, Japan). The relative expression of YMV-CP was calculated after normalization of YMV-CP expression using ubiquitin as reference gene [29].

\section{Results}

\subsection{RNAi Vector Construction and Agrobacterium Transformation}

In order to express virus-derived dsRNA in tobacco, a construct containing 161 bp DNA fragment of yam mosaic virus coat protein in the sense and antisense orientation was produced. The $161 \mathrm{bp}$ fragment was derived from a conserved region between nucleotide 31 and 701 of YMV-CP gene sequences across different strains of YMV. The plasmid, pANDA35HK-YMV-CP contains hpt and nptII genes for selection of transgenic plants. The YMV-CP gene is regulated by $35 \mathrm{~S}$ promoter. To ensure stability of the inverted repeat in Escherichia coli, the two cDNA fragments were separated by a guslinker spacer sequence. The plasmid was mobilized to Agrobacterium tumefaciens strain EHA105 and used for tobacco transformation. A total of twenty transgenic plants were recovered. The T-DNA fragment of pANDA35HK carrying the YMV-CP gene in the sense and antisense orientation is shown in Figure 1.

\subsection{Molecular Characterization of $\mathrm{T}_{0}$ Transgenic Tobacco Plants}

Tobacco explants were successfully transformed with $A$. tumefaciens strain EHA105 harbouring pANDA35HK-YMV-CP, producing transgenic tobacco lines stably expressing YMV-CP gene. Screening of in vitro $\mathrm{T}_{0}$ transgenic tobacco plants by PCR showed that 161 bp fragment of YMV-CP (Figure 2(a)), 557 bp fragment of the selectable marker gene ( $h p t)$ (Figure 2(b)) and 626 bp fragment of guslinker (Figure 2(c)) were amplified in all transgenic lines, but no signal was detected in the wild-type plant. To determine the copy number of the transgene, Southern blot analysis was performed. Result showed transgenic lines having different hybridization profile, with one, two or three transgene insert, suggesting that they regenerated from independent transformation event 
(Figure 3). Northern blot analysis was carried out to detect siRNA in inoculated wild-type and $\mathrm{T}_{0}$ transgenic plants. Results show faint siRNA signals in the transgenic plants while no signal was detected in the mock inoculated wild-type plant (Figure 4).

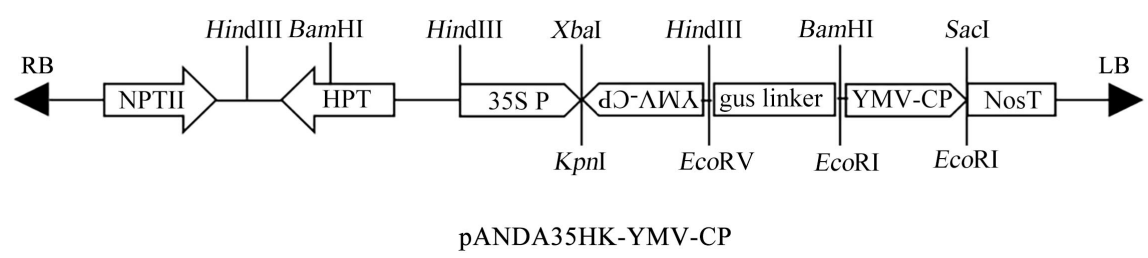

Figure 1. T-DNA region of the RNAi vector pANDA35HK-YMV-CP used for tobacco transformation.
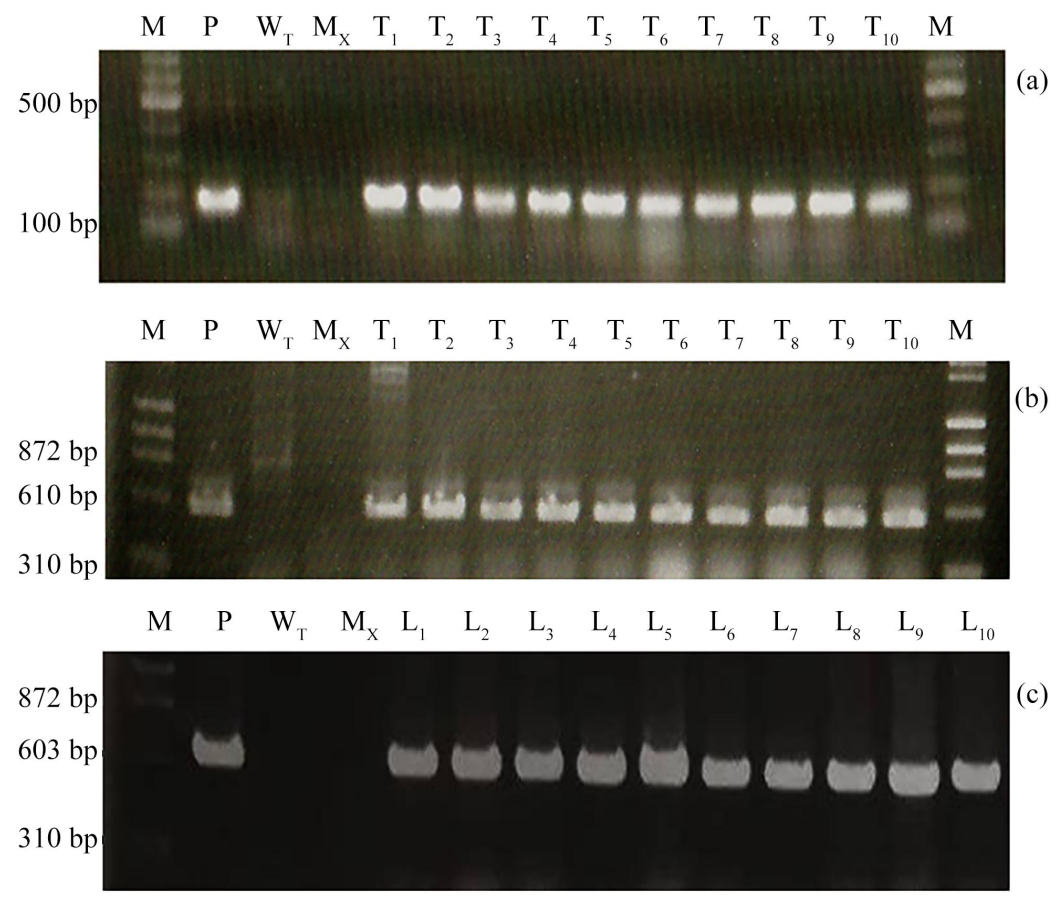

Figure 2. PCR analyses of $\mathrm{T}_{0}$ transgenic tobacco lines expressing dsRNA of YMV-CP gene. (a) YMV-CP gene (161 bp) fragment; (b) hpt gene (557 bp) fragment; (c) Guslinker (626 bp) fragment; $M=100 \mathrm{bp}$ DNA Marker, $\lambda$-HindIII digest/ $\varphi x 174$ HaeIII digest markers; P, pANDA35HK-YMV-CP plasmid; $\mathrm{W}_{\mathrm{T}}$, Wild type; $\mathrm{M}_{\mathrm{X}}$, No-template control; $\mathrm{L}_{1}-\mathrm{L}_{10}$, Putative transgenic lines.

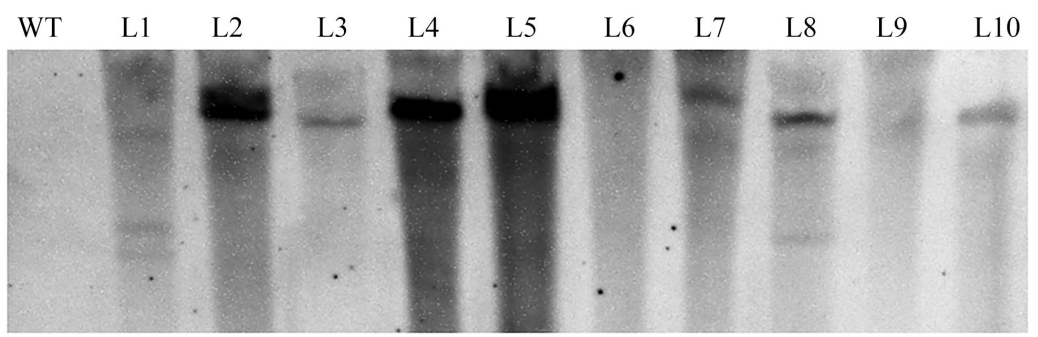

Figure 3. Southern blot analysis of genomic DNA from transgenic and wild-type tobacco plants digested with XhoI, and hybridized with HPT probe. 


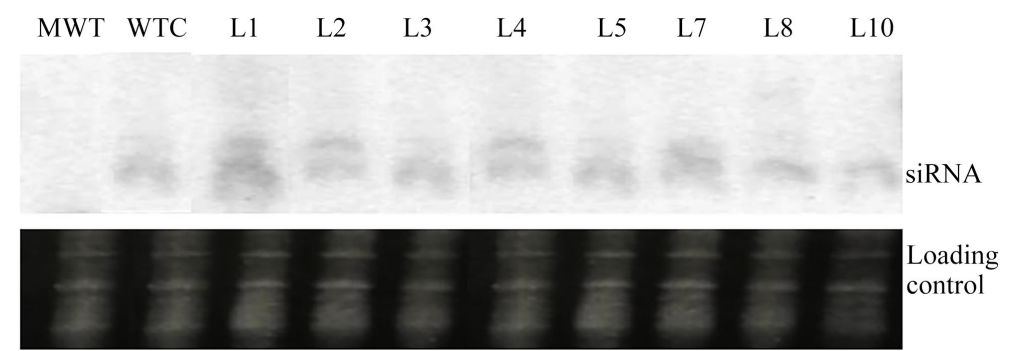

Figure 4. Northern blot analysis to detect YMV-CP -specific siRNA accumulation in tobacco plants after inoculation with YMV. WTC, YMV inoculated wild-type control; MWT, mock inoculated wild-type; $\mathrm{L}_{1}-\mathrm{L}_{10}, \mathrm{~T}_{0}$ transgenic lines.

\subsection{Evaluation of $\mathbf{T}_{0}$ Transgenic Tobacco Lines Inoculated with YMV}

After screening transgenic in vitro plants by PCR and Southern hybridization, positive lines were selected and transferred to the greenhouse for establishment and subsequently inoculated with YMV infection sap. Disease symptom severity on fully expanded leaves was recorded on a scale of 0-3 and disease index calculated using the method earlier described. When transgenic plants were inoculated with YMV, line L2 developed no symptoms on inoculated and emerging new leaves (Figure 5) comparative to the wild-type mock inoculated plants as all the leaves were grouped under grade 0 severity score (Figure 5), consequently, their disease indices were 0 and the plants were classified as being immune to YMV (Table 2) according to the disease rating. The remaining transgenic lines L3, L2, L5, L7, L8 and T10 developed mild symptoms, which were at a much reduced level of severity (grade 1). The disease indices calculated for these lines were very low $(<25 \%)$, hence the lines were classified as being highly resistant to YMV (Table 2). Compared to the transgenic lines, all the emerging new leaves of the wild-type plants developed a range of symptoms, from mild (grade 1) to severe (grade 3) (Figure 5), with $97.8 \%$ of the new leaves having severe disease symptoms. The severity of the disease in the wild-type plants produced high disease indices which was $82.1 \%$ upon inoculation with YMV (Table 2). With the high disease index, the plants were classified as being highly susceptible (HS) to YMV. Plant height was recorded at $60 \mathrm{dpi}$. The mock inoculated wild type plants were significantly taller $(\mathrm{P}<0.001)$ than the inoculated transgenic plants and the inoculated wild-type plants, with mean plant height ranging from $0.59 \pm$ $0.05 \mathrm{~m}$ in YMV inoculated wild-type plants to $1.69 \pm 0.03 \mathrm{~cm}$ in mock inoculated wild-type (Table 2).

\subsection{Detection of YMV by RT-PCR}

Wild-type and transgenic $\mathrm{T}_{0}$ plants inoculated with YMV were evaluated for virus accumulation on new un-inoculated leaves by RT-PCR. The result showed high accumulation of YMV on new un-inoculated leaves of wild-type plants. In contrast, reduced accumulation of YMV was detected on new un-inoculated leaves of $\mathrm{T}_{0}$ transgenic plants (Figure 6). 
Table 2. Evaluation of $\mathrm{T}_{0}$ transgenic and wild-type plants inoculated with YMV under greenhouse conditions.

\begin{tabular}{ccccccc}
\hline $\begin{array}{c}\text { Plant } \\
\text { lines } \\
\text { tested }\end{array}$ & $\begin{array}{c}\text { Plant height } \\
(\mathrm{cm})\end{array}$ & $\begin{array}{c}\text { Number of } \\
\text { plants showing } \\
\text { mosaic } \\
\text { symptoms }\end{array}$ & $\begin{array}{c}\text { Symptoms severity } \\
\text { score } \text { No leaves } \\
\text { per grade } \\
0123\end{array}$ & $\begin{array}{c}\text { Proportion of } \\
\text { leaves with } \\
\text { disease (\%) }\end{array}$ & $\begin{array}{c}\text { Disease } \\
\text { index }(\%)\end{array}$ & $\begin{array}{c}\text { Disease } \\
\text { rating }\end{array}$ \\
\hline MWT & $1.69^{\mathrm{a}} \pm 0.03$ & 0 & 0000 & 0 & NA & NA \\
WTC & $0.59^{\mathrm{e}} \pm 0.05$ & 7 & 01242 & $45 / 46(97.8)$ & 82.1 & HS \\
L1 & $0.98^{\mathrm{c}} \pm 0.03$ & 1 & 38600 & $6 / 44(13.6)$ & 4.5 & HR \\
L2 & $1.32^{\mathrm{b}} \pm 0.07$ & 0 & 36000 & $0 / 36(0)$ & 0 & I \\
L3 & $1.09^{\mathrm{c}} \pm 0.05$ & 3 & 45300 & $3 / 48(6.3)$ & 2.1 & HR \\
L4 & $1.05^{\mathrm{c}} \pm 0.05$ & 1 & 41300 & $3 / 44(6.8)$ & 2.3 & HR \\
L5 & $0.84^{\mathrm{d}} \pm 0.01$ & 2 & 29700 & $7 / 35(20.0)$ & 6.5 & HR \\
L7 & $0.76^{\mathrm{d}} \pm 0.02$ & 4 & 21900 & $9 / 30(30.0)$ & 10.0 & HR \\
L8 & $0.81^{\mathrm{d}} \pm 0.04$ & 1 & 29900 & $9 / 38(23.7)$ & 7.9 & HR \\
L10 & $0.75^{\mathrm{d}} \pm 0.03$ & 2 & 38600 & $6 / 44(13.6)$ & 4.5 & HR \\
\hline
\end{tabular}

Means with dissimilar lower case letters are statistically different $(\mathrm{P}<0.001)$ on the basis of LSD test. MWT $=$ mock inoculated wild-type plant; WTC $=$ YMV inoculated wild-type plant; L1-L10 = transgenic lines; NA = not applicable; $\mathrm{HS}$ = highly susceptible; $\mathrm{HR}=$ highly resistant; $\mathrm{I}=$ immune. Symptom severity grades: 0-no symptom; 1-mild chlorotic pattern; 2-moderate mosaic; class 3-severe mosaic, distortion of the leaflets.

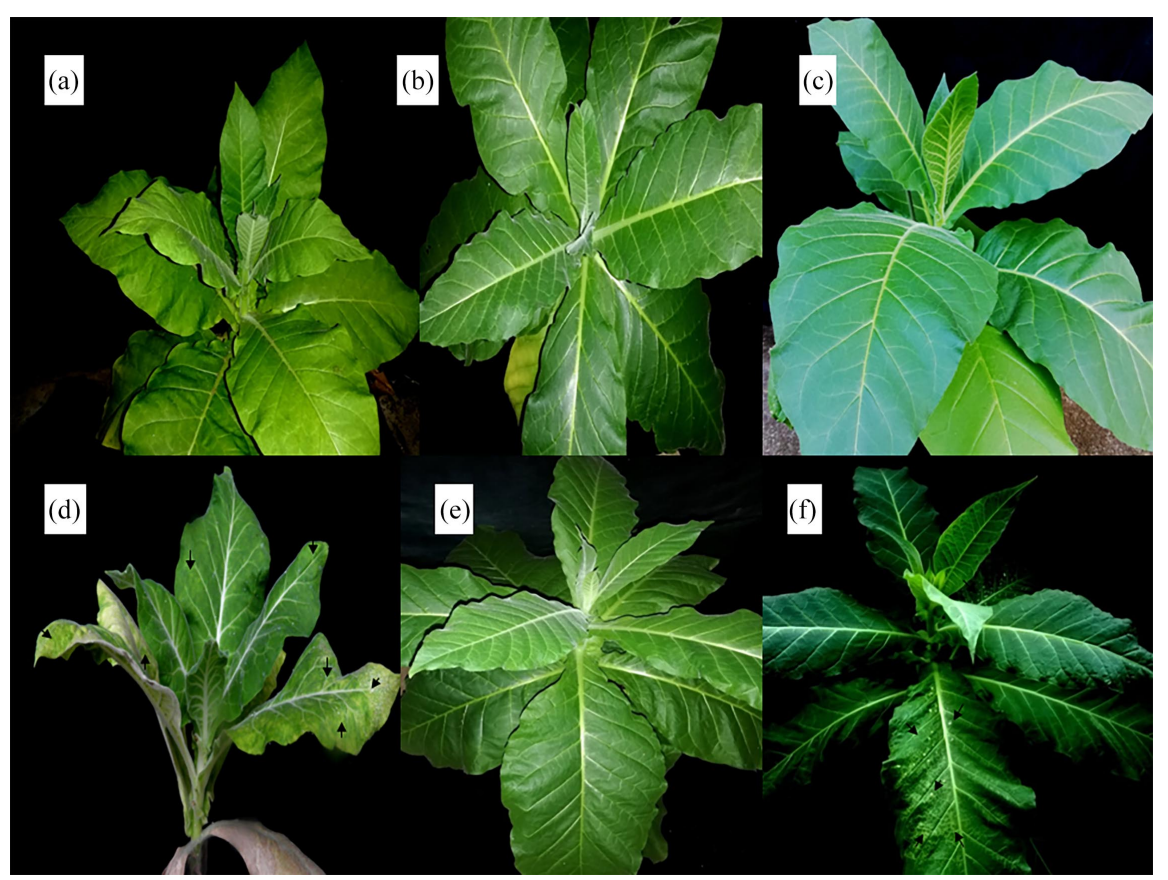

Figure 5. EX vivo evaluation of resistance against YMV. (a, b, c) Wild-type, transgenic tobacco line 2 and line 10 showing no mosaic symptom 2 days after inoculation with YMV; (d) Wild-type control plant showing mosaic symptoms in all emerging leaves 45 after inoculation with YMV; (e) Transgenic tobacco line (line 2) showing complete resistance to YMV 45 days after inoculation with YMV; (f) Transgenic tobacco line (line 10) showing mild mosaic symptoms 45 days after inoculation with YMV. 


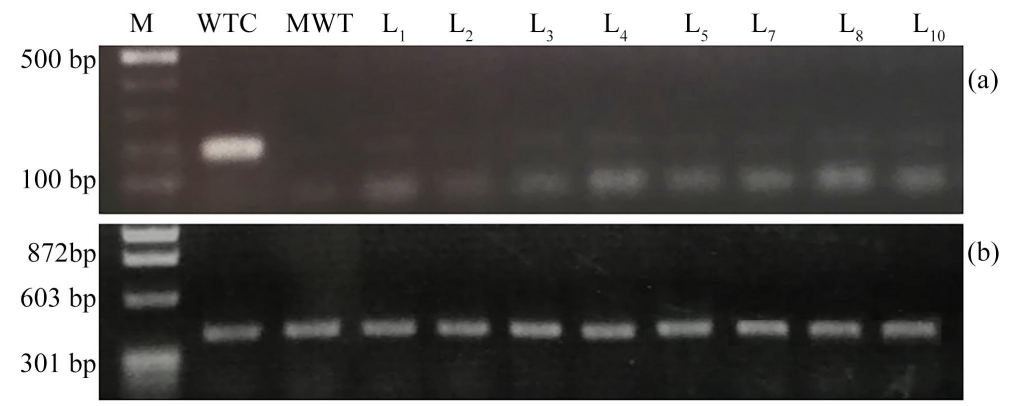

Figure 6. RT-PCR analysis of $\mathrm{T}_{0}$ transgenic tobacco lines expressing dsRNA of YMV-CP gene to determine viral accumulation on new emerging leaves of both wild-type and transgenic lines after inoculation with YMV. (a) YMV-CP; (b) Yam ubiquitin; WTC, YMV inoculated wild-type control; MWT, mock inoculated wild-type; $\mathrm{L}_{1}-\mathrm{L}_{10}, \mathrm{~T}_{0}$ transgenic lines.

\subsection{Evaluation of $T_{1}$ Transgenic Tobacco Lines Inoculated with YMV}

Following the germination of seeds from the $\mathrm{T}_{0}$ transgenic tobacco plants to obtain $T_{1}$ plants, the $T_{1}$ plants were screened for the presence of the target transgene YMV-CP and the selectable marker gene HPT, before they were transferred to the greenhouse for disease assay (Figure 7). After four weeks of acclimatization in the greenhouse, the $T_{1}$ plants were inoculated with YMV infection sap. Lines L2, L3, L5, L6, L7, L8 and wild-type mock inoculated developed no symptoms on inoculated and emerging new leaves as the leaves were grouped under 0 severity score. Consequently, their disease indices were 0 and the plants were classified as being immune to YMV (Table 3) according to the disease rating. The remaining transgenic lines, L4 and L10, developed mild symptoms which were at a much reduced level of severity (grade 1) (Table 3). The disease indices calculated for these lines were very low $(<25 \%)$, hence the lines were classified as being highly resistant to YMV (Table 3). Compared to the transgenic lines, all the emerging new leaves of the wild-type plants developed a range of symptoms, from mild (grade 1) to severe (grade 3). When the plants were inoculated with YMV, 100\% of the new leaves had severe disease symptoms. The severity of the disease in the wild-type plants produced high disease indices which was $78.2 \%$ upon inoculation with YMV (Table 3). With this high disease index, the plants were classified as being highly susceptible (HS) to YMV. Plant height was recorded at 60 dpi. Mock inoculated plants were the tallest but they were not significantly different $(\mathrm{P}>0.05)$ in height from all the transgenic plants except L4 and L10. The wild-type control plants inoculated with YMV were significantly shorter $(\mathrm{P}<0.01)$ than all the other plants $(0.45 \pm 0.02)$ (Table 3$)$.

\subsection{Determination of Virus Accumulation by $q P C R$ in $T_{1}$ Transgenic Tobacco Lines}

Transgenic and wild-type $T_{1}$ tobacco plants inoculated with YMV were evaluated for virus accumulation on new un-inoculated leaves by qPCR. The relative expression of YMV-CP was significantly higher $(\mathrm{P}<0.001)$ in wild-type 
plants, very little or no expression was observed in the transgenic lines (Figure 8).

\section{Discussion}

The use of plant cultivars resistant to viral attack has been known to be the most effective strategy to control viral infections. There are various ways to achieve this, one of which is through genetic engineering. In this study, the main objective was to silent the coat protein gene of yam mosaic virus by RNAi. In potyviruses, coat protein has been identified to be responsible for aphid transmission, cell-to-cell and systemic movement, virus assembly, binding RNA and genome amplification [30] [31].
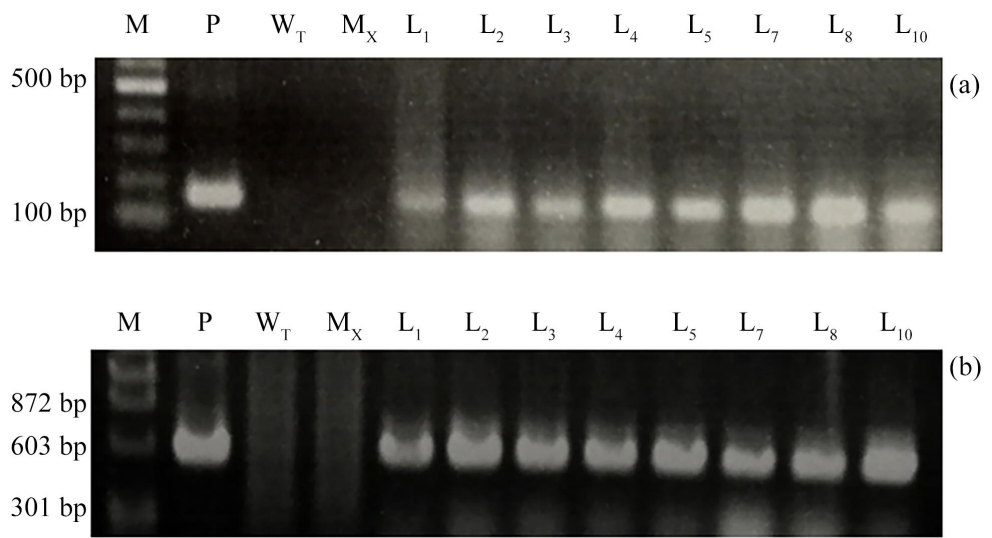

Figure 7. PCR analyses of $T_{1}$ transgenic tobacco lines expressing dsRNA of YMV-CP gene. (a) YMV-CP gene (161 bp) fragment; (b) $h p t$ gene (557 bp) fragment; $\mathrm{M}=100 \mathrm{bp}$ DNA Marker, $\lambda$-HindIII digest/ $\varphi x 174$ HaeIII digest markers; P, pANDA35HK-YMV-CP plasmid; $\mathrm{W}_{\mathrm{T}}$, Wild type; $\mathrm{M}_{\mathrm{X}}$, Non-template control; $\mathrm{L}_{1}-\mathrm{L}_{10}$, Putative transgenic lines.

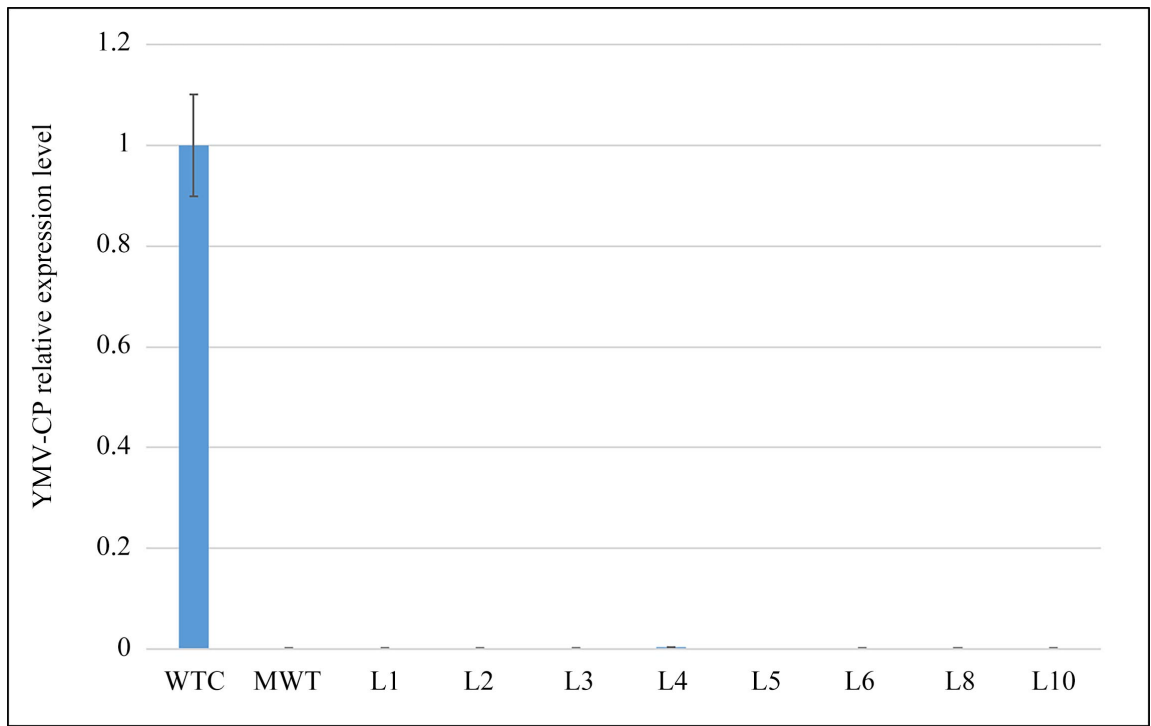

Figure 8. qPCR analysis of $\mathrm{T}_{1}$ transgenic tobacco lines expressing dsRNA of YMV-CP gene to determine the relative expression of YMV-CP gene on new emerging leaves after inoculation with YMV. 
Table 3. Evaluation of $\mathrm{T}_{1}$ transgenic and wild-type plants inoculated with YMV under greenhouse conditions.

\begin{tabular}{ccccccc}
\hline $\begin{array}{c}\text { Plant } \\
\text { lines } \\
\text { tested }\end{array}$ & $\begin{array}{c}\text { Plant height } \\
(\mathrm{cm})\end{array}$ & $\begin{array}{c}\text { Number of } \\
\text { plants showing } \\
\text { mosaic symptoms }\end{array}$ & $\begin{array}{c}\text { Symptoms severity } \\
\text { score/No. of leaves } \\
\text { per grade } 0123\end{array}$ & $\begin{array}{c}\text { Proportion } \\
\text { of leaves with } \\
\text { disease (\%) }\end{array}$ & $\begin{array}{c}\text { Disease } \\
\text { index (\%) }\end{array}$ & $\begin{array}{c}\text { Disease } \\
\text { rating }\end{array}$ \\
\hline MWT & $1.02^{\mathrm{a}} \pm 0.04$ & 0 & 0000 & 0 & NA & NA \\
WTC & $0.45^{\mathrm{c}} \pm 0.02$ & 6 & 01230 & $33 / 33(100)$ & 78.2 & HS \\
L1 & $0.98^{\mathrm{a}} \pm 0.04$ & 0 & 42000 & $0 / 42(0)$ & 0 & I \\
L2 & $0.93^{\mathrm{ab}} \pm 0.05$ & 0 & 46000 & $0 / 46(0)$ & 0 & I \\
L3 & $0.99^{\mathrm{a}} \pm 0.07$ & 0 & 40000 & $0 / 40(0)$ & 0 & I \\
L4 & $0.77^{\mathrm{b}} \pm 0.06$ & 1 & 31800 & $8 / 39(20.5)$ & 9.2 & HR \\
L5 & $0.97^{\mathrm{a}} \pm 0.08$ & 0 & 45000 & $0 / 45(0)$ & 0 & I \\
L7 & $0.92^{\mathrm{ab}} \pm 0.06$ & 0 & 39000 & $0 / 39(0)$ & 0 & I \\
L8 & $1.01^{\mathrm{a}} \pm 0.02$ & 0 & 46000 & $0 / 46(0)$ & 0 & I \\
L10 & $0.80^{\mathrm{b}} \pm 0.09$ & 1 & 25700 & $7 / 32(21.9)$ & 7.3 & HR \\
\hline
\end{tabular}

Means with dissimilar lower case letters are statistically different $(\mathrm{P}<0.001)$ on the basis of LSD test. MWT $=$ mock inoculated wild-type plant; WTC $=$ YMV inoculated wild-type plant; L1-L10 = transgenic lines; NA = not applicable; HS = highly susceptible; HR = highly resistant; I = immune. Symptom severity grades: 0-no symptom; 1-mild chlorotic pattern; 2-moderate mosaic; class 3-severe mosaic and distortion of the leaflets.

In this work, RT-PCR and qPCR analyses for the detection of virus on new leaves of transgenic plants showed that all the transgenic tobacco lines did not contain significant amount of YMV-CP. Thus, the potential risks of heterologous encapsidation and recombination of virus are diminished in these plants. Also, the plants would not be a potential source of virus acquisition by aphids when tried under field conditions. The propagation of plants that display no symptoms but carry a high virus load would be undesirable with regards to virus control under field conditions as such plants would serve as a source of inoculums for subsequent dissemination via aphid [32].

The use of siRNAs, an intermediate in the gene-silencing pathway, has become a powerful tool for down regulation of gene expression, and has been demonstrated successfully in a wide variety of cells and organisms [33]. It is one of the most important characteristics of RNA silencing and can be a reliable molecular marker that is closely associated with viral resistance in transgenic plants [17] [22]. In the present study, siRNA was detected in transgenic $T_{1}$ tobacco lines expressing the YMV-CP derived dsRNA, after inoculation with YMV, except for mock inoculated wild-type plants; indicating that the resistance was acquired through gene silencing. Six $\mathrm{T}_{1}$ transgenic lines showed complete resistance to YMV as no symptoms were spotted even at the inoculated portions, suggesting that the RNAi construct used is a good candidate for PTGS. In $\mathrm{T}_{0}$ and $\mathrm{T}_{1}$ generations of transgenic tobacco plants, some lines and mock inoculated wild-type plants showed no mosaic symptoms on both inoculated and emerging new leaves. In these lines, all the new leaves that appeared afterwards were 
symptomless, suggesting the inability of the virus to move from cell-to-cell and invade new tissues. Also, a few others developed mild symptoms, which were at a much reduced level of severity. These symptoms were limited to inoculated and first new emerging leaves. It could be that the complete PTGS process was not yet fully activated, at least not to levels to fully suppress the systemic movement of the virus. Despite the detection of siRNA in the wild-type plants, they were highly susceptible to YMV inoculations indicating that YMV was actively replicating despite PTGS. Several authors have also reported high siRNA levels in susceptible plants [17] [21] [22] [34] [35]. In the resistant plants, the dsRNA transgene provided additional defense mechanism leading to plant recovery. In the wild-type plant, it seems there was an overlap between the plants suppressing the virus (via PTGS and possibly other mechanisms) and the virus reacting by rapid replication and suppression of the host's silencing mechanism [36] [37]. It has been reported that to overcome the defense mechanism produced by plants, certain plant viruses encode proteins that can suppress the RNA silencing.

In both $T_{0}$ and $T_{1}$ plants, there were no differences between the inoculated transgenic plants and the mock inoculated wild-type plants regarding plant height recorded at $60 \mathrm{dpi}$, as the plants grew normally reaching a height of $1 \mathrm{~m}$ under the period of study. On the contrary, the inoculated wild-type plants were relatively stunted measuring about $0.5 \mathrm{~m}$ high. This result indicates that the silencing of the $\mathrm{CP}$ gene exhibited strong resistance in transgenic plants and did not affect the agronomic performance of the plants, in line with report by Ntui et al. [20]. Several viruses have been reported to infect yams including members of the family Potexviridae; Potyviridae; Bromoviridae; Caulimoviridae [38] [39]. The effectiveness in the induction of resistance to YMV by stable expression of dsRNA of YMV-CP gene in tobacco can be adopted for the induction of resistance in yams against YMV and other yam viruses.

\section{Conclusion}

Our results demonstrate that the resistance of tobacco against YMV infection can be achieved by stable expression of dsRNA of YMV-CP gene. High level expression of the YMV-CP gene did not interfere with general performance of the plants in vitro and under greenhouse conditions. To establish the economic viability of this approach, extensive study of field performance of the transgenic lines to YMV infection will be necessary. This approach could be also used to produce yam resistant to YMV, a major virus affecting its productivity and resulting to huge economic losses.

\section{Acknowledgements}

We thank Bill and Melinda Gates Foundation for a research grant awarded to Valentine Otang Ntui on "Biotechnology approach for producing disease-free, high-performing yam seedlings", grant number OPP1131386. This work was financially supported with funds from the research grant. We are grateful to Prof. 
Ayodeji Timothy Owolabi and Dr. Peter Chukwurah for providing technical assistance.

\section{Authors' Contribution}

VON conceived the original concept and led the study, EEI performed the experiments. VON, EAU and NI supervised the work. All authors wrote the manuscript.

\section{Conflicts of Interest}

The authors declare no conflicts of interest regarding the publication of this paper.

\section{References}

[1] Thouvenel, J.C. and Fauquet, C. (1979) Yam Mosaic, a New Potyvirus Infecting Dioscoreacayenensis in the Ivory Coast. Annals of Applied Biology, 93, 279-283. https://doi.org/10.1111/j.1744-7348.1979.tb06542.x

[2] Aleman-Verdaguer, M., Goudou-Urbino, C., Dubern, J., Beachy, R.N. and Fauquet, C. (1997) Analysis of the Sequence Diversity of the PI, HC, P3, Nib and CP Genomic Regions of Several Yam Mosaic Potyvirus Isolates: Implications for the Intraspecies Molecular Diversity of Potyviruses. Journal of General Virology, 78, 1253-1264. https://doi.org/10.1099/0022-1317-78-6-1253

[3] Thouvenel, J.C. and Dumont, R. (1990) Perte de rendement de l'igname infectee par le virus de la mosaique en Côte d'Ivoire. L'Agronomie Tropicale, 45, 125-129.

[4] Adeniji, M.O., Shoyinka, S.A., Ikotun, T., Asiedu, R., Hughes, J. D’A. and Odu, B.O. (2012) Yield Loss in Guinea Yam (Dioscorea rotundata Poir.) Due to Infection by Yam Mosaic Virus (YMV) Genus Potivirus. Ife Journal of Science, 14, 237-244.

[5] Odu, B.O., Shoyinka, S.A., Hughes, J.D’A., Asiedu, R., Ng, N.Q., Shoyinka, S.A. and Oladiran, O.A. (2004) Responses of White Yam (Dioscorea rotundata) Cultivars to Inoculation with Three Viruses. Plant Pathology, 53, 141-147. https://doi.org/10.1111/j.0032-0862.2004.00997.x

[6] Ita, E.E., Uyoh, E.A., Nakamura, I. and Ntui, V.O. (2020). Efficient Elimination of Yam Mosiac Virus (YMV) from White Yam (Dioscorea rotundata) by Cryotherapy of Axillary Buds. South African Journal of Botany, 130, 123-129. https://doi.org/10.1016/j.sajb.2019.12.022

[7] Cogoni, C. and Macino, G. (2000) Post-Transcriptional Genesilencing across Kingdoms. Current Opinion in Genetics and Development, 10, 638-643. https://doi.org/10.1016/S0959-437X(00)00134-9

[8] Fire, A., Xu, S., Montgomery, M.K., Kostas, S.A., Driver, S.E. and Mello, C.C. (1998) Potent and Specific Genetic Interference by Double-Stranded RNA in Caenorhabditis elegans. Nature, 391, 806-811. https://doi.org/10.1038/35888

[9] Bonfim, K., Faria, J.C., Nogueria, E.L., Mandes, E.A. and Aragao, J.L. (2007) RNA-Mediated Resistance to Bean Golden Virus in Genetically Engineered Common Bean (Phaseolus vulgaris). Molecular Plant-Microbe Interactions Journal, 20, 717-726. https://doi.org/10.1094/MPMI-20-6-0717

[10] Elbashir, S.M., Lendeckel, W. and Tuschl, T. (2001) RNA Interference Is Mediated by 21 - and 22-Nucleotide RNAs. Genes Development, 15, 188-200. https://doi.org/10.1101/gad.862301 
[11] Susi, P., Hohkuri, M., Wahlroos, T. and Kilby, N.J. (2004) Characteristics of RNA Silencing in Plants: Similarities and Differences across Kingdoms. Plant Molecular Biology, 54, 157-174. https://doi.org/10.1023/B:PLAN.0000028797.63168.a7

[12] Tenallado, F., Live, C. and Diaze-Ruiz, J.R. (2004) RNA Interference as New Biotechnological Tool for Control of Virus Diseases in Plants. Virus Research, 102, 85-96. https://doi.org/10.1016/j.virusres.2004.01.019

[13] Poggin, M.M., Shivaprasad, P.V., Veluthambi, K. and Hohn, T. (2003) Rnai Targeting of DNA Viruses in Plants. Nature Biotechnology, 21, 131-132. https://doi.org/10.1038/nbt0203-131b

[14] Vanderschuren, H., Alder, A., Zhang, P. and Gruissem, W. (2009) Dose-Dependent Rnai-Mediated Geminivirus Resistance in the Tropical Root Crop Cassava. Journal of Plant Biology, 70, 265-272. https://doi.org/10.1007/s11103-009-9472-3

[15] Ntui, V.O., Kynet, K., Khan, R.S., Igawa, T., Janavi, G.J., Rabindran, R., Nakamura, I. and Mii, M. (2015) Resistance to Sri Lanka Cassava Mosaic Virus (SLCMV) in Genetically Engineered Cassava Cv. KU50 through RNA Silencing. PLoS ONE, 10, e0120551. https://doi.org/10.1371/journal.pone.0120551

[16] Tricoll, D.M., Camey, K.J., Russell, P.F., Mcmaster, J.R., Groff, D.W., Hadden, K.C., Himmel, P.T., Hubbard, J.P., Boeahore, M.L. and Quemada, H.D. (1995) Field Evaluation of Transgenic Squash Containing Single or Multiple Virus Coat Protein Gene Constructs for Resistance to Cucumber Mosaic Virus, Watermelon Mosaic Virus 2, and Zucchini Yellow Mosaic Virus. Nature Biotechnology, 13, 1458-1465. https://doi.org/10.1038/nbt1295-1458

[17] Kalantidis, K., Psaadakis, S., Tabler, M. and Tsagris, M. (2002) The Occurrence of CMV-Specific Shot RNAs in Transgenic Tobacco Expressing Virus-Derived DoubleStranded RNA Is Indicative of Resistance to the Virus. Molecular Plant-Microbe Interactions Journal, 15, 826-833. https://doi.org/10.1094/MPMI.2002.15.8.826

[18] Klas, F.E., Fuchs, M. and Gonsalves, D. (2006) Comparative Spatial Spread over Time of Zucchini Yellow Mosaic Virus (ZYMV) and Watermelon Mosaic Virus (WMV) in Fields of Transgenic Squash Expressing the Coat Protein Gene of ZYMV and WMV, and in Fields of Non-Transgenic Squash. Transgenic Research, 15, 527-541. https://doi.org/10.1007/s11248-006-9001-y

[19] Ntui, V.O., Kynet, K., Azadi, P., Khan, R.S., Chin, D.P., Nakamura, I. and Mii, M. (2013) Transgenic Accumulation of Defective Cucumber Mosaic Virus (CMV) Replicase Derived Double Stranded RNA Modulates Plant Defence against CMV Strains O and Y in Potato. Transgenic Research, 22, 1191-1205.

https://doi.org/10.1007/s11248-013-9721-8

[20] Ntui, V.O., Kynet, K., Khan, R.S., Watanabe, M., Ohara, M., Fukami, M., Nakamura, I. and Mii, M. (2014) Transgenic Tobacco Lines Expressing a Detective CMV Replicase Derived dsRNA Are Resistant to CMV-O and Y. Molecular Biotechnology, 56, 50-63. https://doi.org/10.1007/s12033-013-9681-5

[21] Ntui, V.O., Kynet, K., Azadi, P., Khan, R.S., Igawa, T., Nakamura, I. and Mii, M. (2014) RNAi-Mediated Resistance to Cucumber Mosaic Virus in Genetically Engineered Tomato. American Journal of Plant Science, 5, 554-572. https://doi.org/10.4236/ajps.2014.55071

[22] Missiou, A., Kalantidis, K., Boutlas, A., Tzortzakaki, S., Tabler, M. and Tsagris, M. (2004) Generation of Transgenic Potato Plants Highly Resistant to Potato Virus Y (PVY) through RNA Silencing. Molecular Breeding, 14, 185-194. https://doi.org/10.1023/B:MOLB.0000038006.32812.52

[23] Thomas, P.E., Lawson, E.C., Zalewski, J.C., Reed, G.L. and Kaniewski, W.K. (2000) Extreme Resistance to Potato Leafroll Virus in Potato Cv. Russet Burbank Mediated 
by the Viral Replicase Gene. Virus Research, 71, 49-62. https://doi.org/10.1016/S0168-1702(00)00187-8

[24] Krubphachaya, P., Juricek, M. and Kertbundit, S. (2007) Induction of RNA-Mediated Resistance to Papaya Ringspot Virus Type W. Journal of Biochemistry and Molecular Biology, 40, 404-411. https://doi.org/10.5483/BMBRep.2007.40.3.404

[25] Kundu, J.K., Braird, P., Hily, J.M., Ravelonandro, M. and Scorza, R. (2008) Role of the 25-26 nt siRNA in the Resistance of Transgenic Prunus domestica Graft Inoculated with Plum pox virus. Virus Genes, 36, 215-220. https://doi.org/10.1007/s11262-007-0176-y

[26] Hily, J.M., Scorza, R., Malinowski, T., Zawadzka, B. and Ravelnonandro, M. (2004) Stability of Gene Silencing-Based Resistance to Plum pox virus in Transgenic Plum (Prunus domestica L.) under Field Conditions. Transgenic Research, 13, 427-436. https://doi.org/10.1007/s11248-004-8702-3

[27] Kong, K., Ntui, V.O., Makabe, S., Khan, R.S., Mii, M. and Nakamura, I. (2014) Transgenic Tobacco and Tomato Plants Expressing Wasabi Defensin Gene Driven by Root-Specific LJNRT2 and AtNRT2.1 Promoters Confer Resistance against Fusarium oxysporium. Plant Biotechnology, 31, 89-96.

[28] Ogawa, Y. and Mii, M. (2007) Meropenem and Moxalactam: Novel B-Lactam Antibiotics for Efficient Agrobacterium-Mediated Transformation. Plant Science, 172, 564-572. https://doi.org/10.1016/j.plantsci.2006.11.003

[29] Livak, K.J. and Schmittgen, T.D. (2001) Analysis of Relative Gene Expression Data Using Real-Time Quantitative PCR and the $2^{-\Delta \Delta C_{T}}$ Method. Methods, 25, 402-408. https://doi.org/10.1006/meth.2001.1262

[30] Shukla, D.D., Frenkel, M.J. and Ward, C.W. (1991) Structure and Function of the Potyvirus Genome with Special Reference to the Coat Protein Coding Region. Canadian Journal of Plant Pathology, 13, 178-191. https://doi.org/10.1080/07060669109500953

[31] Plisson, C., Drucker, M., Blanc, S., German-Retana, S., Le, G.O., Thomas, D. and Bron, P. (2003) Structural Characterization of HC-Pro, a Plant Virus Multifunctional Protein. Journal of Biological Chemistry, 278, 23753-23761. https://doi.org/10.1074/jbc.M302512200

[32] Ntui, V.O., Thirukkumaran, G., Azadi, P., Khan, R.S., Nakamura, I. and Mii, I. (2010) Stable Integration and Expression of Wasabi Defensin Gene in "Egusi" Melon (Colocynthis citrullus L.) Confers Resistance to Fusarium Wilt and Alternaria Leaf Spot. Plant Cell Reports, 29, 943-954.

https://doi.org/10.1007/s00299-010-0880-2

[33] Chellappan, P., Masona, M.V., Vanitharani, R., Taylor, N.J. and Fauquet, C.M. (2004) Broad Spectrum Resistance to ssDNA Viruses Associated with Transgene-Induced Gene Silencing in Cassava. Plant Molecular Biology, 56, 601-611. https://doi.org/10.1007/s11103-004-0147-9

[34] Mitter, N., Sulistyowati, E. and Dietzgen, R.G. (2003) Cucumber Mosaic Virus Infection Transiently Breaks dsRNA-Induced Transgenic Immunity to Potato Virus Y in Tobacco. Molecular Plant-Microbe Interactions, 16, 936-944. https://doi.org/10.1094/MPMI.2003.16.10.936

[35] Simone, G.R., Hendrikus, L., Rob, G. and Marcel, P. (2007) Tomato Chlorotic Mottle Virus Is a Target of RNA Silencing but the Presence of Specific Short Interfering RNAs Does Not Guarantee Resistance in Transgenic Plants. Journal of Virology, 81, 1563-1573. https://doi.org/10.1128/JVI.01238-06

[36] Kasschau, K.D. and Carrington, J.C. (1998) A Counter Defensive Strategy of Plant 
Viruses: Suppression of Posttranscriptional Gene Silencing. Cell, 95, 461-470. https://doi.org/10.1016/S0092-8674(00)81614-1

[37] Voinnet, O., Pinto, Y.M. and Baulcombe, D.C. (1999) Suppression of Gene Silencing: A General Strategy Used by Diverse and RNA Viruses of Plants. Proceedings of the National Academy of Sciences of the United States of America, 96, 14147-14152. https://doi.org/10.1073/pnas.96.24.14147

[38] Hughes, J.D’A., Dongo, L.N. and Atiri, G.I. (1997) Viruses Infecting Cultivated Yams (Dioscorea alata and D. rotundata) in Nigeria. Phytopathology, 87, 545.

[39] Odu, B.O., Hughes, J.D’A., Shoyinka, S.A. and Dongo, L.N. (1999) Isolation, Characterisation and Identification of a Potyvirus from Dioscorea alata L. (Water Yam) in Nigeria. Annals of Applied Biology, 134, 65-71.

https://doi.org/10.1111/j.1744-7348.1999.tb05236.x 